\title{
İnsani Gelişmenin Ekonomik ve Politik Belirleyicileri: Panel Sıralı Nitel Tercih Analizi
} (Araştırma Makalesi)

Economic and Political Determinants of Human Development: Panel

Ordered Qualitative Choice Analysis

Doi: 10.29023/alanyaakademik.808788

Rabia EFEOĞLU

Dr. Ögrr. Üyesi, Kastamonu Üniversitesi, İktisadi ve İdari Bilimler Fakültesi, Finans ve

Bankacılık Bölümü

refeoglu@kastamonu.edu.tr

Orcid No: 0000-0003-2515-1553

Bu makaleye atıfta bulunmak için: Efeoğlu, R. (2021). "İnsani Gelişmenin Ekonomik ve Politik Belirleyicileri: Panel Siralı Nitel Tercih Analizi”. Alanya Akademik Bakış, 5(2), Sayfa No.911-923.

\begin{tabular}{|c|c|}
\hline & 1 \\
\hline $\begin{array}{l}\text { Anahtar kelimeler: } \\
\text { İnsani Gelişme } \\
\text { Endeksi, İktisadi } \\
\text { Hoşnutsuzluk } \\
\text { Endeksi, Ekonomik } \\
\text { Özgürlük, Politik } \\
\text { İstikrar, Demokrasi } \\
\text { Makale Geliş Tarihi: } \\
\text { 10.10.2020 } \\
\text { Kabul Tarihi: } \\
\text { 26.04.2021 }\end{array}$ & $\begin{array}{l}\text { Çalışmanın amacı, düşük, orta, yüksek ve çok yüksek insani gelişime sahip } \\
128 \text { ülkede insani gelişmenin ekonomik ve politik belirleyicileri olan iktisadi } \\
\text { hoşnutsuzluk endeksi, ekonomik özgürlük, politik istikrar ve demokrasi gibi } \\
\text { değişkenlerin insani gelişmişlik üzerine etkisini test etmektir. Çalışmada } \\
2010-2018 \text { dönemine ait veriler kullanılarak panel sıralı nitel tercih analizi } \\
\text { gerçekleştirilmiştir. Analiz sonucuna göre ülkelerin ekonomik ve politik } \\
\text { belirleyicileri olan iktisadi hoşnutsuzluk endeksi, ekonomik özgürlük, politik } \\
\text { istikrar ve demokrasi değişkenlerinin insani gelişmenin çok yüksek } \\
\text { düzeylerinde daha etkili ve çok yüksek insani gelişme düzeyini etkileme } \\
\text { olasıllğının daha yüksek olduğu sonucu elde edilmiştir. }\end{array}$ \\
\hline $\begin{array}{l}\text { Keywords: } \\
\text { Human Development } \\
\text { Index, Misery Index, } \\
\text { Economic Freedom, } \\
\text { Political Stability, } \\
\text { Democracy }\end{array}$ & $\begin{array}{l}\text { The aim of the study is to test the effect of variables such as misery index, } \\
\text { economic freedom, political stability and democracy, which are economic and } \\
\text { political determinants of human development in } 128 \text { countries with low, } \\
\text { medium, high and very high human development. In the study, panel ordered } \\
\text { qualitative choice analysis was carried out using data from the 2010-2018 } \\
\text { period. According to the results of the analysis, it was concluded that the } \\
\text { misery index, economic freedom, political stability and democracy variables, } \\
\text { which are the economic and political determinants of the countries, are more } \\
\text { effective at very high levels of human development and is higher likely to effect } \\
\text { very high level of human development. }\end{array}$ \\
\hline
\end{tabular}

\section{GİRIŞ}

Ülkelerin gelişmişlik düzeylerinin ölçülmesinde en yaygın kullanılan ölçüt insani gelişme endeksidir. Ülkelerin gelişiminde ekonomik, sosyal, kültürel ve politik boyut önem arz etmektedir. 1970'li y1llarda ilginçtir, iktisatta insani boyut bir kenara itilirken, ekonomik 
kalkınmada insani boyutu esas alan insani gelişme kavramı gündemde yerini alarak en çok tartışılan güncel konu haline gelmiştir. Böylece politik istikrarsızlık ve işsizliğin artması gibi nedenlerle gözden düşmeye başlayan insani gelişme yeniden önem kazanmaya başlamıştır. $\mathrm{Bu}$ anlamda insani gelişmenin belirleyicisi olarak politik istikrar ile enflasyon ve işsizliğin toplamından oluşan hoşnutsuzluk endeksinin kullanılması önem arz etmiştir.

Birleşmiş Milletler Kalkınma Programı (UNDP), insani gelişimi; "insanların seçim şanslarının arttığı, alternatiflerin genişlediği bir süreç” şeklinde tanımlamaktadır. 1990 yılından itibaren UNDP tarafından hesaplanan endeks uzun ve sağlıklı bir yaşam, bilgiye ulaşılabilirlik, insan onuruna yakışır bir yaşam standardı olmak üzere 3 boyut üzerinden hesaplanmaktadır. Endeks hesaplanırken öncelikle 3 boyutu temsil eden doğumda yaşam beklentisi endeksi, eğitim endeksi ve gelir endeksi hesaplanır, daha sonra da üç endeksin geometrik ortalaması alınarak insani gelişme endeksi hesaplanır. İnsani gelişme endeksi 0 ile 1 arasında değer almaktadır. Endeksin 1'e yaklaşması insani gelişmişlik düzeyinin arttığını, 0'a yaklaşması insani gelişmişlik düzeyinin azaldığını gösterir.

Çalışmada insani gelişmenin ekonomik ve politik belirleyicileri ele alınacağından ekonomik belirleyicilerden ilki iktisadi hoşnutsuzluk endeksidir. İktisadi Hoşnutsuzluk Endeksi Amerikalı iktisatçı Arthur Okun tarafından 1970 yılında ortaya atılmıştır. Endeks enflasyon oranı ile işsizlik oranının toplamından oluşmaktadır. Endeksin yükselmesi iktisadi hoşnutsuzluğun arttığını, endeksin düşmesi iktisadi hoşnutsuzluğun azaldığını göstermektedir. Diğer bir ifadeyle enflasyon ve işsizlik makroekonomik performans göstergeler olduğundan endeksin artması makroekonomik performansın kötüleştiğini, azalması makroekonomik performansın iyileştiğini göstermektedir. Enflasyon ve işsizlik oranlarının artması ise ekonomik ve sosyal maliyetlere sebep olmaktadır. Enflasyon ve işsizliğin artışı hoşnutsuzluk endeksini artırmakla birlikte yoksullaşmayı beraberinde getirmekte yoksullaşma da refah kaybına neden olmaktadır.

Ekonomik belirleyicilerden ikincisi ekonomik özgürlüktür. Özellikle 1990’lı y1llardan itibaren ülkelerin ekonomik gelişiminde önemli bir rol oynayan ekonomik özgürlükler; mal ve hizmetlerin üretim, dağıtım ve tüketiminde devlet tarafından yapılan kısıtlamaların olmaması, devlet müdahalesinin olmaması olarak ifade edilmektedir. Ekonomik özgürlüğün olduğu ülkelerde devletin rolü azalmakta, serbest piyasa koşulları hakim olmaktadır. Ekonomik özgürlükler Heritage Vakfı tarafından yayınlanan Ekonomik Özgürlükler Endeksi ve Fraser Enstitüsü tarafından hazırlanan Dünya Ekonomik Özgürlüğü Endeksi olmak üzere iki farklı endeks ile ölçülmektedir. Ancak kapsam olarak daha geniş, daha fazla ülkeyi değerlendirmeye alan ve literatürde çoğunlukla kullanılan endeks Heritage Foundation tarafından oluşturulan ekonomik özgürlük endeksidir. Endeks 0 ile 100 arasında değerler almaktadır. Yüksek değerler yüksek özgürlük seviyesini göstermektedir. 0’a yaklaştıkça ekonomik özgürlük azalmakta, 100'e yaklaştıkça ekonomik özgürlük artmaktadır.

İnsani gelişmenin sağlanmasında ekonomik belirleyicilerin yanı sıra politik belirleyiciler de önemli bir yer tutmaktadır. $\mathrm{Bu}$ anlamda çalışmada kullanılan politik belirleyicilerden ilki politik istikrardır. Politik istikrar siyasal sistemin şiddet, kaba kuvvet, zorlama ve yıkıcılıktan uzak olması, siyasal sistemin temel unsurlarının pek değişmemesi, siyasal süreçte kesintilerin olmamasıyla, toplumda siyasal sistemi temelden değiştirmek isteyen önemli sosyal güçlerin ve siyasal hareketlerin bulunmaması olarak tanımlanabilir. Ölçümü, Dünya Bankası tarafından hesaplanan iyi yönetişimin unsurlarından biri olan politik istikrar endeksi ile yapılmaktadır. Endeks değerindeki artış politik istikrarın arttığını, azalış politik istikrarın azaldığını gösterir.

912 
Politik belirleyicilerden ikincisi demokrasidir. Demokrasi, en genel tanımıyla halkın kendi kendini yönetmesidir. Arat Demokrasi Endeksi, Banks Demokrasi Endeksi, Bollen Liberal Demokrasi Endeksi, Poe ve Tate Demokrasi Endeksi, Vanhannen Endeksi, Polity Endeksi ve Freedom House Endeksi gibi çeşitli endeksler ile ölçülen demokrasi her ülkede farklı düzeydedir. Söz konusu endeksler içerisinde Freedom House Endeksi tüm çalışmalarda en yaygın ve yoğunlukla kullanılan ve bu çalışmada da kullanılacak olan bir endekstir. Freedom House demokrasi endeksi siyasi haklar ve sivil özgürlüklere dayanan, en yüksek demokrasi düzeyi 1, en düşük demokrasi düzeyi 7 olan ve ülkeleri özgür, kısmen özür ve özgür olmayan ülkeler olarak sınıflandıran bir endekstir.

Literatürde insani gelişime etkileri bakımından farklı araştırmalar yapılmış ve her araştırmada farklı sonuçlara ulaşılmıştır. Literatürde farklı ülke grupları için analizler gerçekleştirilmiş olsa da insani gelişme düşük, orta, yüksek ve çok yüksek insani gelişme sınıflandırmasına bağlı olarak tüm ülkeler açısından önem arz etmektedir. Çalışmanın amacı düşük, orta, yüksek ve çok yüksek insani gelişime sahip 128 ülkede ekonomik ve politik belirleyicilerin insani gelişime etkisini araştırmaktır. Çalışmayı diğer çalışmalardan ayıran yönü düşük, orta, yüksek ve çok yüksek insani gelişime sahip ülkeleri bir arada incelemekle birlikte, bağımlı değişken insani gelişme endeksinin kategorik ve sıralı bir nitelik taşıması dolayısıyla sıralı nitel tercih modellerinin kullanılarak analiz edilmesidir. Ayrıca literatürde insani gelişime etkisi incelenen, az sayıda kullanılan iktisadi hoşnutsuzluk endeksi ve politik istikrar değişkenlerinin analizlere dahil edilmesi çalışmayı diğer çalışmalardan ayırmaktadır. Çalışma beş bölümden oluşmaktadır. Giriş bölümünden sonra literatür taraması, üçüncü bölümde veri seti ve yöntem, dördüncü bolümde analiz, beşinci bolümde sonuçlar sunulmaktadır.

\section{LITERATÜR TARAMASI}

Literatürde insani gelişme üzerine yapılan ekonomik ve politik faktörlerin insani gelişime etkisini inceleyen çok sayıda çalışma vardır ve her biri farklı yöntemler kullanarak farklı sonuçlar elde etmiştir. Çalışmalar genel olarak panel veri analizlerine dayanmaktadır. Yapılan çalışmalarda genel kanı ekonomik ve politik faktörlerdeki artışın insani gelişmeyi pozitif etkilediği yönündedir. Bu kısımda sadece çalışmada ekonomik ve politik belirleyiciler olarak nitelendirilen iktisadi hoşnutsuzluk endeksi ve ekonomik özgürlük ile politik istikrar ve demokrasi değişkenlerinin insani gelişime etkisini inceleyen ampirik çalışmalara değinilecektir.

Grubel (1998) yaptığ çalışmada, 78 ülkede ekonomik özgürlük ve insani gelişme ilişkisini 1996-1997 dönemi için panel veri analiz yöntemiyle incelemiştir. Çalışma sonucuna göre, ekonomik özgürlük insani gelişmişlik düzeyini artırmaktadır.

Welzel ve Inglehart (2001), 60 ülke için demokratikleşmenin insani gelişme üzerindeki etkisini incelemişler, demokratikleşmenin insani gelişmeyi olumlu etkilediği sonucuna varmışlardır.

Akhter (2004), 109 ülke için 1998 döneminde ekonomik özgürlük, küreselleşme, yolsuzluk ve insani gelişme ilişkisini incelemiş, ekonomik özgürlügüun insani gelişme üzerinde olumlu, yolsuzluğun insani gelişme üzerinde olumsuz bir etkisinin olduğu sonucuna varmıştır.

Ross (2006), 168 ülke için 1970-2000 döneminde politik özgürlüğün insani refah üzerine etkisini panel veri analizi yöntemiyle incelemiş, politik özgürlüğün insani refahı mutlak anlamda artırmadığı sonucuna varmıştır. 
Tsai (2006) yaptığı çalışmada 119 ülkede demokratikleşmenin insani gelişme üzerindeki etkisini regresyon yöntemiyle incelemiş, demokrasinin insani gelişmeyi artırdığı bulgusunu elde etmiştir.

Chodak ve Kowal (2011), 132 ülke için ekonomik özgürlük ve insani gelişme arasındaki ilişkiyi incelemişlerdir. 2009 dönemi verilerinin kullanıldığı çalışmada ekonomik özgürlük göstergesi olarak Heritage Foundation Ekonomik Özgürlük Endeksi, insani gelişme göstergesi olarak UNDP İnsani Gelişme Endeksi kullanılarak korelasyon analizi yapılmıştır. Buna göre ekonomik özgürlük insani gelişmeyi artırmaktadır.

Berggren (2012) yaptığı çalışmada, 146 ülkede demokrasi ve insani gelişme arasındaki ilişkiyi 1980-2010 dönemi için panel veri analiz yöntemiyle incelemiștir. Demokrasi göstergesi olarak Freedom House demokrasi endeksini, insani gelişme göstergesi olarak UNDP İnsani Gelişme Endeksini kullanmıştır. Çalışma sonucuna göre, demokrasi insani gelişmeyi pozitif yönde etkilemektedir.

Gerring vd. (2012), 1960-2000 döneminde 159 ülke için demokrasi ve insani gelişme ilişkisini panel veri analiz yöntemiyle test etmişler, demokrasinin insani gelişmeyi olumlu etkilediği sonucunu elde etmişlerdir.

Saha ve Zhang (2012) "The Impact of the Interaction between Economic Growth and Democracy on Human Development: Cross-National Analysis" adlı çalışmalarında 170 ülke için 1980-2010 dönemi verileriyle panel veri analiz yöntemini kullanarak demokrasi ve ekonomik büyümenin insani gelişme üzerindeki etkisini incelemişlerdir. Buna göre demokrasi insani gelişmeyi artırmaktadır.

Imandoust ve Montazeri (2013), OPEC ülkelerinde demokrasi ve insani gelişme arasındaki ilişkiyi 1996-2010 dönemi verileriyle panel veri analiz yöntemini kullanarak araştırmışlardır. Demokrasi göstergesi olarak Polity2 demokrasi endeksi, insani gelişme göstergesi olarak UNDP İnsani Gelişme Endeksini kullanmışlar, demokrasinin insani gelişmeyi pozitif ve anlamlı etkilediği sonucuna varmışlardır.

Kicsi ve Burciu (2014), kalkınma ve ekonomik özgürlük arasındaki ilişkiyi regresyon analiziyle 178 ülke için incelemişlerdir. Ekonomik özgürlük göstergesi olarak Heritage Foundation Ekonomik Özgürlük Endeksini, kalkınma göstergesi olarak UNDP İnsani Gelişim Endeksini kullanmışlardır. Buna göre ekonomik özgürlük insani gelişmeyi olumlu etkilemektedir.

Georgiou (2015), panel veri analiz yöntemiyle 2000-2012 döneminde Avrupa Birliği, Japonya ve Birleşmiş Milletler ülkeleri için ekonomik özgürlük ve insani gelişme endeksi ilişkisini test etmiştir. Ekonomik özgürlüğün arttıkça insani gelişme endeksinin arttığı sonucunu elde etmiştir.

Gerring vd. (2015) çalışmalarında demokrasinin insani gelişme üzerindeki etkisini araştırmışlardır. Demokrasi göstergesi olarak Multiplicative Electoral Democracy Index, insani gelişme göstergesi olarak bebek ölümleri, çocuk ölümleri ve doğumda yaşam beklentisinin kullanıldığı çalışma sonucuna göre, demokrasinin seçim yönü insani gelişim ile doğrusal yönde bir ilişki içerisindedir.

Miller (2015) yaptığı çalışmada, 158 ülkede seçim otoriterliği ve insani gelişme arasındaki ilişkiyi 1960-2007 dönemi için panel veri analiz yöntemiyle incelemiştir. Çalışma sonucuna göre, otoriter rejimlerdeki seçim sistemleri insani gelişmeyi artırmaktadır. 
Annaka ve Higashima (2017), 173 ülke için 1800-2015 dönemi verileriyle panel veri analiz yöntemini kullanarak demokrasinin insani gelişme üzerine etkisini incelemişlerdir. Demokrasi göstergesi olarak Polity II demokrasi endeksini, insani gelişme göstergesi olarak bebek ölüm oranlarını kullanmışlardır. Analiz sonuçlarına göre, demokrasinin artışı bebek ölüm oranlarını azaltmakta, yani insani gelişmeyi artırmaktadır.

Güney (2017), ekonomik özgürlük ve insani gelişme arasındaki ilişkiyi 1990-2014 döneminde panel veri analiz yöntemini kullanarak 21 OECD ülkesi için incelemiştir. İnsani gelişmişlik göstergesi olarak UNDP tarafından yayınlanan İnsani Gelişme Endeksini, ekonomik özgürlük göstergesi olarak Fraser Institute tarafından yayınlanan Ekonomik Özgürlük Endeksini kullanmıştır. Elde ettiği sonuca göre, ekonomik özgürlük insani gelişmeyi pozitif yönlü etkilemektedir.

Pehlivanoğlu ve Alabaş (2017) tarafından yapılan çalışmada, 1996-2014 dönemi için Türkiye'de kurumların insani gelişme üzerine etkisi zaman serisi yöntemi ile analiz edilmiştir. Kurumsal gösterge olarak Dünya Yönetişim Göstergeleri, insani gelişme göstergesi olarak İnsani Gelişme Endeksi kullanılmıştır. Kurumsal göstergelerden hükümetin etkinliği, hukukun üstünlüğü ve politik istikrarın insani gelişmeyi pozitif etkilediği bulgusuna ulaşılmıştır.

Çoban ve Yayar (2018), panel veri analiz yöntemiyle demokrasinin insani gelişme üzerine etkisini 2007-2014 döneminde Avrupa Birliği ülkeleri için test etmişlerdir. Demokrasi göstergesi olarak Mülkiyet Hakları Endeksini, insani gelişme göstergesi olarak Birleşmiş Milletler Kalkınma Programı (UNDP) İnsani Gelişmişlik Endeksini kullanmışlardır. Demokrasi ve insani gelişme arasında pozitif bir ilişkinin olduğu sonucu elde edilmiştir.

Liotti vd. (2018), 1990-2014 döneminde 18 Sovyet ülkesi için demokrasinin insani gelişme üzerindeki etkisini panel veri analiz yöntemiyle test etmişlerdir. Çalışmada demokrasi ile insani gelişme arasında pozitif yönlü bir ilişkinin olduğu sonucu elde edilmiştir.

Naanwaab (2018), "Does Economic Freedom Promote Human Development? New Evidence from a Cross-National Study" adlı çalışmasında 88 gelişmekte olan ülkede ekonomik özgürlüklerin insani gelişme üzerine etkisini 1990-2008 dönemi için panel veri analiz yöntemiyle incelemiştir. İnsani gelişmişlik göstergesi olarak UNDP tarafından yayınlanan İnsani Gelişme Endeksini, ekonomik özgürlük göstergesi olarak Fraser Institute tarafından yayınlanan Ekonomik Özgürlük Endeksini kullanmıştır. Çalışma sonucuna göre, ekonomik özgürlük arttıkça insani gelişme artmaktadır.

Graafland (2019), "Contingencies in the Relationship between Economic Freedom and Human Development: The Role of Reneralized Trust" adlı çalışmasında 29 OECD ülkesi için 19902015 dönemi verileriyle panel veri analiz yöntemini kullanarak ekonomik özgürlük ve insani gelişme arasındaki ilişkiyi incelemiştir. Buna göre ekonomik özgürlük arttıkça insani gelişme artmaktadir.

Güzel ve Erdoğan (2019), Türkiye'nin 1990-2017 dönemi verileriyle demokrasi ve gelir eşitsizliğinin insani gelişme üzerine etkisini panel veri analiz yöntemiyle test etmişlerdir. Demokrasi göstergesi olarak Polity IV demokrasi endeksini, insani gelişme göstergesi olarak UNDP İnsani Gelişme Endeksini kullanmışlardır. Çalışmada demokrasinin insani gelişmeyi artırdığı sonucu elde edilmiştir. 
Özdemir ve Salihoğlu (2019), ekonomik ve politik faktörlerin insani gelişmişlik üzerindeki etkilerini 40 ülke için panel veri analiz yöntemini kullanarak incelemişlerdir. Ekonomik faktör göstergeleri olarak ekonomik özgürlük endeksi ve hoşnutsuzluk endeksini; politik faktör göstergeleri olarak politik istikrar endeksi, küresel barış endeksi ve yaşam memnuniyeti endeksini kullanmışlardır. Buna göre ekonomik özgürlük endeksi, hoşnutsuzluk endeksi ve politik istikrar endeksi ile insani gelişme endeksi arasında pozitif; küresel barış endeksi ve yaşam memnuniyeti endeksi ile insani gelişmişlik endeksi arasında negatif yönlü bir ilişki vardir.

Çoban (2020), Çekya, Macaristan, Slovakya ve Polonya ülkeleri için 1995-2014 döneminde ekonomik özgürlüklerin insani gelişime etkisini panel veri analiz yöntemiyle incelemiştir. Ekonomik özgürlüklerin insani gelişmişlik seviyesini olumlu etkilediği, ekonomik özgürlügün arttıkça insani gelişmenin arttığı sonucuna varmıştır.

Khan vd. (2020), Pakistan için 2006-2018 döneminde en küçük kareler yöntemini kullanarak insani gelişme ve politik istikrar ilişkisini incelemişler, politik istikrarın insani gelişmeyi artırdığı sonucuna varmışlardır.

Korle vd. (2020), 1996-2017 dönemi verileriyle ekonomik özgürlük ve doğrudan yabanc1 sermaye yatırımlarının insani gelişme üzerine etkisini 32 Afrika ülkesinde panel veri analizi yöntemiyle incelemişlerdir. Ekonomik özgürlük göstergesi olarak Heritage Foundation Ekonomik Özgürlük Endeksi, insani gelişme göstergesi olarak UNDP İnsani Gelişme Endeksini kullanmışlar ve ekonomik özgürlüğün insani gelişmeyi artırdığı sonucuna varmışlardır.

\section{VERI SETİ VE YÖNTEM}

Çalışmada ekonomik belirleyiciler olan iktisadi hoşnutsuzluk endeksi ve ekonomik özgürlük endeksi ile politik belirleyiciler olan politik istikrar ve demokrasinin insani gelişmişlik üzerindeki etkisi incelenmektedir. Dolayısıyla ekonomik ve politik belirleyicilerin insani gelişime üzerindeki etkisi amaçlanmaktadır. Çalışmada oluşturulan iktisadi model fonksiyonel olarak aşağıdaki gibidir:

$$
\dot{\mathrm{IGE}}=\mathrm{f}\left(\mathrm{IKKT} \_\mathrm{HOS}, \mathrm{EKO} \mathrm{O} Z\right. \text { Z, POL_İST, DEM) }
$$

İGE, insani gelişme düzeyini göstermekte olup, bağımlı değişken olarak insani gelişme endeksini; İKT_HOS ve EKO_ÖZ ekonomik belirleyiciler olup, bağımsız değişkenler olarak iktisadi hoşnutsuzluk endeksi ve ekonomik özgürlük endeksini; POL_İST ve DEM politik belirleyiciler olup, bağımsız değişkenler olarak politik istikrar ve demokrasi endeksini ifade etmektedir. Bağımlı değişkenin sıralı sayı olması sebebiyle analizlerde sıralı probit modellerin kullanılmasının daha uygun olacağı söylenebilir.

Sıralı probit model başlangıç olarak (Özer, 2004, 93):

$$
\mathrm{Y}^{*}=\beta^{\prime} \mathrm{X}+\varepsilon
$$

olarak ele alınabilir. Modelde $\mathrm{Y}^{*}$ gözlenemeyen sürekli tesadüfi bir değişken; $\varepsilon$ ortalaması 0 , varyansı 1 olan normal dağılımlı bir tesadüfi değişkendir. Buna göre $\mathrm{Y}^{*}$;

$$
\mathrm{Y}=\mathrm{j} \text { sadece ve sadece } \mu \mathrm{j}<\mathrm{Y}^{*}<\mu \mathrm{j}+1 \text { ise }(\mathrm{j}=0,1, \ldots ., \mathrm{J})
$$


kuralı gereğince Y'nin alacağı değerleri belirlemektedir. Yani gözlenen Y değişkeni gözlenemeyen $\mathrm{Y}^{*}$ değişkeninden türetilmektedir. Bundan dolayı da $\mathrm{Y}^{*}$ gözlenemezse bile, buna bağlı olarak değişkenler aşağıdaki şekilde belirlenebilir ve gözlenen $\mathrm{Y}$ değişkeni gözlemlenemeyen $\mathrm{Y} *$ değişkeni yardımıyla şu şekilde tanımlanır:

$$
\begin{array}{ll}
\mathrm{Y}=0 & \mathrm{Y} * \leq 0 \text { ise } \\
=1 & 0<\mathrm{Y}^{*} \leq \mu 1 \text { ise } \\
=2 & \mu 1<\mathrm{Y}^{*} \leq \mu 2 \text { ise } \\
=\mathrm{J} & \mu \mathrm{j}-1 \leq \mathrm{Y}^{*} \quad \text { ise }
\end{array}
$$

Burada $\mu$ 'ler eşik değerleri olup $\beta$ 'lar ile birlikte tahmin edilecek bilinmeyen parametrelerdir.

Bağımlı değişkenin bu değerleri alma olasılıkları sıralı probit model için aşağıdaki şekilde yazılabilir:

$$
\begin{aligned}
& \mathrm{P}(\mathrm{Y}=0)=\Phi\left(-\beta^{\prime} \mathrm{X}\right) \\
& \mathrm{P}(\mathrm{Y}=1)=\Phi\left(\mu 1-\beta^{\prime} \mathrm{X}\right)-\Phi\left(-\beta^{\prime} \mathrm{X}\right) \\
& \mathrm{P}(\mathrm{Y}=2)=\Phi\left(\mu 2-\beta^{\prime} \mathrm{X}\right)-\Phi\left(\mu 1-\beta^{\prime} \mathrm{X}\right) \\
& \mathrm{P}(\mathrm{Y}=\mathrm{J})=1-\Phi\left(\mu \mathrm{j}-1-\beta^{\prime} \mathrm{X}\right)
\end{aligned}
$$

Tüm olasılıkların pozitif olması aşağıdaki gibi bir kısıta bağlıdır:

$$
0<\mu 1<\mu 1<\ldots<\mu \mathrm{j}-1
$$

Her bir olasılık durumu üç kategori için aşağıdaki gibidir:

$$
\begin{aligned}
& \mathrm{P}(\mathrm{Y}=0 \mid \mathrm{X})=1-\Phi\left(-\beta^{\prime} \mathrm{X}\right) \\
& \mathrm{P}(\mathrm{Y}=1 \mid \mathrm{X})=\Phi\left(\mu-\mathrm{X}^{\prime} \beta\right)-\Phi\left(-\mathrm{X}^{\prime} \beta\right) \\
& \mathrm{P}(\mathrm{Y}=2 \mid \mathrm{X})=1-\Phi\left(\mu-\mathrm{X}^{\prime} \beta\right)
\end{aligned}
$$

$\mathrm{Bu}$ üç olasılık için marjinal etkiler ise;

$$
\begin{aligned}
& \partial \mathrm{P}(\mathrm{Y}=0 \mid \mathrm{X}) / \partial \mathrm{X}=-\Phi\left(-\mathrm{X}^{\prime} \beta\right) \beta \\
& \partial \mathrm{P}(\mathrm{Y}=1 \mid \mathrm{X}) / \partial \mathrm{X}=\left[\Phi\left(-\mathrm{X}^{\prime} \beta\right)-\Phi\left(\mu-\mathrm{X}^{\prime} \beta\right)\right] \beta \\
& \partial \mathrm{P}(\mathrm{Y}=2 \mid \mathrm{X}) / \partial \mathrm{X}=\Phi\left(\mu-\mathrm{X}^{\prime} \beta\right) \beta
\end{aligned}
$$

şeklinde gösterilir. Marjinal etkiler, bağımlı değişken ile bağımsız değişkenler arasındaki ilişkiyi ölçmekte ve bağımsız değişkenlerdeki değişmelerin bağımlı değişken üzerindeki her bir tercihin olasılı̆̆ını göstermektedir.

Çalışmada düşük, orta, yüksek ve çok yüksek insani gelişime sahip 128 ülkenin 2010-2018 dönemi verileri kullanılarak ekonomik ve politik belirleyicilerin insani gelişme üzerine etkisi sıralı nitel tercih analizi ile araştırılmıştır. Araştırmada kullanılan değişkenler, değişkenlerin açıklaması ve elde edildikleri kaynaklar aşağıda Tablo 1'de sunulmuştur.

Tablo 1. Kullanılan Değişkenler ve Kaynakları

$\begin{array}{llll}\text { Değişken } & \begin{array}{l}\text { Değişken } \\ \text { Türü }\end{array} & \text { Açıklama } & \text { Kaynak } \\ & \end{array}$




\begin{tabular}{|c|c|c|c|}
\hline İGE & $\begin{array}{l}\text { Bağımli } \\
\text { Değişken }\end{array}$ & $\begin{array}{l}\text { İnsani gelişme ölçüsü } \\
\text { olup insani gelişme } \\
\text { endeksine } \\
\text { dayanmaktadır. } \\
\text { Düşük, orta, yüksek, } \\
\text { çok yüksek olmak } \\
\text { üzere dört düzeyli } \\
\text { kategori olarak } \\
\text { ölçeklendirilmiştir. }\end{array}$ & $\begin{array}{l}\text { Human Develpoment Index } \\
\text { http://hdr.undp.org/ }\end{array}$ \\
\hline İKT_HOS & $\begin{array}{l}\text { Bağımsız } \\
\text { Değişken }\end{array}$ & $\begin{array}{l}\text { İktisadi Hoşnutsuzluk } \\
\text { Endeksidir. }\end{array}$ & $\begin{array}{l}\text { World Bank, } \\
\text { World Development Indicator (WDI) } \\
\text { https://databank.worldbank.org/data/ }\end{array}$ \\
\hline EKO_ÖZ & $\begin{array}{l}\text { Bağımsız } \\
\text { Değişken }\end{array}$ & $\begin{array}{l}\text { Ekonomik özgürlük } \\
\text { endeksidir. } 0 \text { ile } 100 \\
\text { arasında değer alır. } \\
\text { 0'a yaklaştıkça } \\
\text { özgürlük azalmakta, } \\
\text { 100'e yaklaştıkça } \\
\text { artmaktadır. }\end{array}$ & $\begin{array}{l}\text { Heritage Foundation } \\
\text { https://www.heritage.org/index/explore }\end{array}$ \\
\hline POL_İST & $\begin{array}{l}\text { Bağımsız } \\
\text { Değişken }\end{array}$ & Politik istikrar & $\begin{array}{l}\text { World Bank, } \\
\text { Worldwide Governance Indicator (WGI) } \\
\text { https://info.worldbank.org/governance/wgi/ }\end{array}$ \\
\hline DEM & $\begin{array}{l}\text { Bağımsız } \\
\text { Değişken }\end{array}$ & $\begin{array}{l}\text { Freedom House } \\
\text { endeksidir. } 1 \text { ile } 7 \\
\text { arasında değer alır. } 1 \\
\text { en yüksek demokrasi } \\
\text { düzeyi, } 7 \text { en düşük } \\
\text { demokrasi düzeyidir. }\end{array}$ & $\begin{array}{l}\text { Freedom House } \\
\text { https://freedomhouse.org/ }\end{array}$ \\
\hline
\end{tabular}

İGE bağımlı değişken olup insani gelişmişlik düzeyini gösteren insani gelişme endeksi değişkenidir. İnsani gelişme endeksinin en düşük değeri 0, en yüksek değeri 1'dir. Yani düşük değerler (0'a yaklaştıkça) düşük insani gelişme düzeyini, çok yüksek değerler (1'e yaklaştıkça) çok yüksek insani gelişme düzeyini ifade etmektedir. Endeks düşük, orta, yüksek ve çok yüksek insani gelişme düzeyi olmak üzere dört kategoriye ayrılarak, insani gelişme düzeyi düşük düzey insani gelişmeden çok yüksek düzey insani gelişmeye (1'den 4'e) doğru dört düzeyde gösterilmiştir. 1. düzey düşük düzey insani gelişme, 2. düzey orta düzey insani gelişme, 3 . düzey yüksek düzey insani gelişme ve 4. düzey çok yüksek düzey insani gelişmedir. İKT_HOS iktisadi hoşnutsuzluk endeksi, EKO_ÖZ ekonomik özgürlük endeksi, POL_İST politik istikrar, DEM demokrasi bağımsız değişkenleridir.

Çalışmada bağımlı değişken olarak kullanılan insani gelişme endeksi 0 ile 1 arasında değerler alan sıralı bir değişken olduğu için ekonometrik yöntem olarak sıralı nitel tercih modelleri kullanılmaktadır. Dolayısıyla sıradan en küçük kareler tahmin yöntemini kullanarak regresyon modelini tahmin etmek yerine siralı nitel tercih modellerini kullanmak daha uygun olacaktır. Literatürde bu durum birçok çalışmada göz ardı edilmektedir. Çalışmada insani gelişme endeksi değişkeninin sıralı ve kategorik bir nitelik taşıması dolayısıyla değişkeni açıklamada daha uygun olan sıralı logit ve probit model tahmini yapılmaktadır. Böylece insani gelişme endeksini kullanarak en çok olabilirliği esas alan sıralı logit ve probit tahminleri ile literatüre bir katkı amacı güdülüp, literatürü destekleyip desteklemediği belirlenmeye çalışılmaktadır. 


\section{ANALIZ}

Siralı nitel tercih modelleri olan sıralı logit ve sıralı probit modellerinden hangisinin analizde kullanılacağına karar vermek için her iki model de tahmin edilmiştir. Tablo 2'de sıralı nitel tercih modellerinden sıralı logit ve probit insani gelişme modellerinin karşılaştırılması sonuçları görülmektedir.

Tablo 2. Sıralı Logit ve Probit İnsani Gelişme Modellerinin Karşılaştırılması

\begin{tabular}{lcc}
\hline Model & Siralı Logit Model & Siralı Probit Model \\
\hline IKT_HOS & $0.019^{* * * *}$ & $0.014^{* * *}$ \\
EKO_ÖZ & $0.187^{* * *}$ & $0.107^{* * *}$ \\
POL_İST & $1.085^{* * *}$ & $0.645^{* * *}$ \\
DEM & $-0.346^{* * *}$ & $-0.203^{* * *}$ \\
\hline McFadden R ${ }^{2}$ & 0.312 & 0.314 \\
AIC (Akaike bilgi kriteri) & 2151.784 & 2147.597 \\
BIC (Bayes bilgi kriteri) & 2187.128 & 2182.942 \\
Log likelihood & -1068.891 & -1066.798 \\
LR istatistik & 970.49 & 974.68 \\
Prob.(LR) & 0.000 & 0.000 \\
Gözlem Sayıs1 & 1152 & 1152 \\
\hline
\end{tabular}

Not: ***, ** ve * işaretleri, \%1, \%5 ve \%10 düzeylerinde istatistiksel anlamlılığ göstermektedir.

Sıralı logit ve probit modeller birbirlerine çok benzer olmakla birlikte literatürde modellerden hangisinin tercih edileceğine dair çeşitli kriterler mevcuttur. Buna göre yapılan analizler sonucu ortaya çıkan bilgi kriterleri (AIC ve BIC) ile pseudo R2'ne göre karar verilebilmektedir. Şayet sıralı probit modeldeki bilgi kriterleri sıralı logit modeldeki bilgi kriterlerinden düşük ve sıralı probit modeldeki pseudo R2 değeri sıralı logit modeldeki pseudo R2 değerinden büyükse sıralı probit model tercih edilmektedir. Tablo 2'de siralı probit modelde bilgi kriterleri sıralı logit modele göre düşük olup, pseudo R2 değerleri bakımından daha büyüktür. Bu kriterlere göre sıralı probit modelin seçilmesi uygun olacaktır.

Tablo 3. Suralı Probit Model Tahmin Sonuçları

\begin{tabular}{lclll}
\hline Bağımsız Değişkenler & Katsayılar & Standart Hata & z-değeri & Marjinal Etkiler \\
\hline IKT_HOS & $0.014 * * *$ & 0.004 & 3.03 & 0.004 \\
EKO_ÖZ & $0.107 * * *$ & 0.005 & 18.87 & 0.037 \\
POL_İST & $0.645^{* * *}$ & 0.054 & 11.85 & 0.223 \\
DEM & $-0.203 * * *$ & 0.021 & -9.54 & -0.070 \\
\hline Gözlem Sayıs1 & 1152 & & & \\
Prob>Ki-Kare & 0.0000 & & & \\
Pseudo R & 0.3136 & & &
\end{tabular}

Not: ***, ** ve * işaretleri, \%1, \%5 ve \%10 düzeylerinde istatistiksel anlamlılığı göstermektedir.

Tablo 3 'te birinci sütunda bağımsız değişkenler, ikinci sütunda sıralı probit model sonucu elde edilen katsayılar, üçüncü sütunda katsayılara ait standart hatalar, dördüncü sütunda katsayıların $\mathrm{z}$ değerleri ve beşinci sütunda bağımsız değişkenlerin bağımlı değişken üzerindeki marjinal etkileri görülmektedir. Probit modeller doğrusal bir model olmadıklarından probit model tahmin sonucu elde edilen katsayılar doğrudan yorumlanamamakta ancak, katsayıların işaretleri üzerinde durulabilmektedir. $\mathrm{Bu}$ nedenle probit modellerde katsayıları yorumlayabilmek için marjinal etkiler hesaplanmaktadır. Marjinal etkiler hesaplandıktan sonra 
her bir katsayı yorumlanabilmekte, z değerlerinin olasılık değerlerine göre de katsayıların istatistiki bakımdan anlamlılıklarına bakılabilmektedir. Yani modelde her bir bağımsız değişkenin insani gelişme düzeyi üzerindeki sayısal etkisi incelenmektedir. Marjinal etki, bağımsız değişken bir birim arttığında insani gelişme düzeyi kategorisindeki değişme olasılığını göstermektedir. İnsani gelişme düzeyleri düşük düzey insani gelişme, orta düzey insani gelişme, yüksek düzey insani gelişme ve çok yüksek düzey insani gelişme olarak dört kategoriye ayrılmıştır. Değerlendirmede yalnızca çok yüksek insani gelişme düzeyine ilişkin marjinal etkiler gösterilmektedir.

Tahmin edilen panel sıralı nitel tercih modeli (sıralı probit model) sonuçlarına göre tüm bağımsız değişkenler (iktisadi hoşnutsuzluk endeksi, ekonomik özgürlük endeksi, politik istikrar ve demokrasi endeksi) \%1 düzeyinde istatistiksel olarak anlamlıdır. Diğer taraftan değişkenlere ait katsayı işaretleri beklentisi iktisadi hoşnutsuzluk endeksi ve demokrasi endeksi için negatif, ekonomik özgürlük endeksi ve politik istikrar için pozitiftir. Çünkü demokrasi değişkeni 1 ve 7 değerleri arasında olup 1 en yüksek değeri, 7 en düşük değeri gösterdiğinden demokrasi değişkeninin işaretinin negatif olması beklenmektedir. İktisadi hoşnutsuzluk endeksi ve demokrasi endeksi düşerse (demokrasi düzeyi artarsa), ekonomik özgürlük ve politik istikrar artarsa insani gelişme endeksi artar. Çalışmada ekonomik özgürlük, politik istikrar ve demokrasi değişkenlerinin katsayı işaretleri beklenildiği gibi çıkmıştır. Ekonomik özgürlük endeksi ve politik istikrar değişkenleri insani gelişme düzeyi ile pozitif ilişkili, demokrasi değişkeni negatif ilişkilidir. İktisadi hoşnutsuzluk değişkeninin ise katsayı işareti beklendiği gibi çıkmamıştır. Ancak iktisadi hoşnutsuzluk endeksinin insani gelişme ile ilişkisinde çok düşük bir değerde pozitif ilişkili olduğu dikkat çekmektedir. Katsayıları yorumlayabilmek için tahminde marjinal etkiler bağımlı değişkenin sadece çok yüksek insani gelişme kategorisi üzerindeki marjinal etkilerini göstermektedir. Hesaplanan marjinal etki sonuçlarına göre; iktisadi hoşnutsuzluk endeksi değişkenine ait marjinal etki bu değişkenin insani gelişme düzeyine ilişkin en yüksek kategorinin olasılığını 0.004 birim arttırmaktadır. Ekonomik özgürlük endeksi değişkenine ait marjinal etki bu değişkenin insani gelişme düzeyine ilişkin en yüksek kategorinin olasılığını 0.037 birim arttırmaktadır. Politik istikrar değişkenine ait marjinal etki bu değişkenin insani gelişme düzeyine ilişkin en yüksek kategorinin olasılığını 0.223 birim arttırmaktadır. Demokrasi değişkenine ait marjinal etki bu değişkenin insani gelişme düzeyine ilişkin en yüksek kategorinin olasılığını 0.070 birim azaltmaktadır. Yani demokrasi endeksi düştükçe demokrasi artmakta bu da insani gelişme düzeyini artırmaktadır. Bir başka deyişle, iktisadi hoşnutsuzluk endeksi, ekonomik özgürlük ve politik istikrar arttıkça ve demokrasi endeksi düştükçe insani gelişme endeksi artmakta, insani gelişme düzeyi de artmaktadır. Ayrıca tahmin edilen sıralı probit modelde ki-kare test istatistiğine göre model bir bütün olarak anlamlıdır. Sıralı probit modelde modelin uygun olup olmadığ1 uyum iyiliği "Sözde $R 2$ Değeri (Pseudo $R 2$ )" testi ile yapılmaktadır. Buna göre bağımlı değişkendeki toplam değişimin \%31'i bağımsız değişkenler tarafindan açıklanabilmektedir.

\section{SONUÇ}

Çalışmada ekonomik ve politik belirleyicilerin insani gelişme düzeyi üzerindeki etkisi düşük, orta, yüksek ve çok yüksek insani gelişime sahip 128 ülke için 2010-2018 dönemi verileri kullanılarak ampirik olarak araştırılmıştır. Ekonomik belirleyiciler olarak iktisadi hoşnutsuzluk endeksi ve ekonomik özgürlük endeksi, politik belirleyiciler olarak politik istikrar ve demokrasi verisi kullanılmıştır. Bağımlı değişken olarak kullanılan insani gelişme endeksi; sıralı ve 
kategorik bir nitelik taşıdığından, ekonomik ve politik belirleyicilerin insani gelişme düzeyi üzerindeki etkisini belirlemek için panel sıralı nitel tercih analiz yöntemi kullanılmıştır.

Çalışmanın analiz sonuçlarına göre, ekonomik ve politik belirleyicilerin tamamı istatistiksel olarak anlamlıdır ve iktisadi hoşnutsuzluk endeksi haricindeki değişkenlerin katsayı işaretleri beklenilen yöndedir. Ancak iktisadi hoşnutsuzluk endeksi işaret bakımından beklenti yönünde çıkmasa da etki yönünden düşük olduğu ve bu düşük etki ile insani gelişmeyi etkilediği unutulmamalıdır. Buna göre iktisadi hoşnutsuzluk endeksi, ekonomik özgürlük endeksi ve politik istikrar değişkenleri insani gelişme düzeyine ilişkin en yüksek kategorinin olasılığını artırırken, demokrasi azaltmaktadır. Bir diğer değişle demokrasi endeksindeki azalış (demokrasi düzeyindeki artış) ve iktisadi hoşnutsuzluk endeksi, ekonomik özgürlük endeksi ve politik istikrar değişkenlerindeki artış insani gelişmeyi artırmaktadır.

Sıralı probit model tahmin sonuçlarına göre, insani gelişmenin daha yüksek seviyelerinde ekonomik ve politik belirleyicilerin insani gelişme üzerinde daha etkili olduğu söylenebilir. Çünkü insani gelişmenin düşük, orta ve yüksek düzeylerinde ekonomik ve politik belirleyicilerin insani gelişmeyi etkileme olasılığı düşük iken, çok yüksek insani gelişme düzeyini etkileme olasılığı yüksektir. Diğer bir ifadeyle insani gelişmenin düşük, orta ve yüksek düzeylerinde ekonomik ve politik belirleyicilerin insani gelişme üzerindeki etkisi çok yüksek insani gelişme düzeyine göre daha düşüktür.

Çalışma iktisadi hoşnutsuzluk, ekonomik özgürlük, politik istikrar ve demokrasi ile temsil edilen ekonomik ve politik belirleyicilerin artması durumunda insani gelişmenin artacağını göstermektedir. Böylece çalışmada ulaşılan sonuçlar ile literatürde yer alan çalışmalar karşılaştırıldığında; ekonomik özgürlüğün insani gelişmeyi artırdığı yönündeki Grubel (1998), Akhter (2004), Chodak ve Kowal (2011), Kicsi ve Burciu (2014), Georgiou (2015), Güney (2017), Naanwaab (2018), Graafland (2019), Özdemir ve Salihoğlu (2019), Çoban (2020), Korle vd. (2020) literatürleri; iktisadi hoşnutsuzluğun insani gelişmeyi artırdığı yönündeki Özdemir ve Salihoğlu (2019) literatürü; politik istikrarın insani gelişmeyi artırdığ 1 yönündeki Pehlivanoğlu ve Alabaş (2017), Özdemir ve Salihoğlu (2019), Khan vd. (2020) literatürleri; demokrasinin insani gelişmeyi artırdığı yönündeki Welzel ve Inglehart (2001), Tsai (2006), Berggren (2012), Gerring vd. (2012), Saha ve Zhang (2012), Imandoust ve Montazeri (2013), Gerring vd. (2015), Miller (2015), Annaka ve Higashima (2017), Çoban ve Yayar (2018), Liotti vd. (2018), Güzel ve Erdoğan (2019) literatürleri ile örtüşmektedir. Bununla birlikte literatürde Ross (2006) çalışmasında politik özgürlüğün insan refahını artırmadığı sonucu ile çalışma literatürden ayrışmaktadır. Özetle, ekonomik özgürlük, politik istikrar ve demokrasi insani gelişmeyi artıran unsurlardır. Ülkelerde ekonomik ve politik belirleyici olarak bu unsurlarda meydana gelecek artışların insani gelişmeyi artıracağı anlaşılmaktadır.

Politika önermesi olarak; ülkelerde ekonomik iyileşme ile birlikte siyasal iyileşmenin de olması gerekmektedir. Ülkelerin insani gelişmişliklerini sağlamaları ve daha ileri düzeye taşımaları ekonomik ve politik etkenlerin birlikte gelişimi ile mümkün olabilmektedir. Çünkü politik istikrar ve demokrasinin olmadığı toplumlarda belirsizlik hakim olmakta bu durum da ülke refahının belirsizliğine yol açabilmektedir. Hoşnutsuzluk endeksi düşürülmeye çalışılıp, işsizlik azaltılarak istihdamın artırılması gerekmekle birlikte ülkelerde istihdamın önündeki yapısal engellerin tespit edilerek kaldırılması, ülkeler tarafından fiyat istikrarı sağlanarak enflasyonun kontrol altına alınması uygun olabilir. Enflasyon ve işsizliğin kontrol altına alınması insani gelişmişlik düzeyinin artmasını sağlayacaktır. Söz konusu ülkelerde ekonomik 
özgürlük ve politik istikrarın daha da yükseltilmesini sağlayacak çalışmalar, düzenlemeler ve politikalar uygulanabilir. Böylece ülkelerde insani gelişmişlik düzeyi daha da yükselecektir.

\section{KAYNAKÇA}

AKHTER, S. (2004). "Is Globalization What It's Cracked Up to Be? Economic Freedom, Corruption, and Human Development”. Journal of World Business, 39(3), 1-22.

ANNAKA, S. \& HIGASHIJIMA, M. (2017). "Democratization and Human Development". WINPEC Working Paper, No.1712, 1-35.

BERGGREN, O. (2012). "Democracy and Development A Cross-National Analysis". Lund University Bachelor of Science in Development Studies Department of Political Science. STVK12 Bachelor's Thesis.

CHODAK, G. \& KOWAL, K. (2011). "Degree of Economic Freedom and Relationship to Economic Growth and Human Development". MPRA, 36712, 1-11.

ÇOBAN, M. N. (2020). "Ekonomik Özgürlüklerin İnsani Gelişmişlik Üzerine Etkisi: Visegrad Dörtlüsü Kapsamında Panel Veri Analizi”. TESAM Akademi Dergisi, 7(1), 143-162.

ÇOBAN, M. N. \& YAYAR, R. (2018). “Demokrasinin Göstergelerinin İnsani Gelişmişlik Üzerine Etkisi: AB Ülkeleri Üzerine Bir Panel Veri Analizi”. International Journal of Academic Value Studies, 4(20), 642-651.

GEORGIOU, M. N. (2015). "Economic Freedom and Human Development Index. A Panel Data Analysis (2000- 2012)". Economics, 1-6.

GERRING, J., THACKER, S. C. \& ALFARO, R. (2012). "Democracy and Human Development". The Journal of Politics, 74(1), 1-17.

GERRING, J., KNUTSEN, C. H., SKAANing, S. E., TEORELl, J., MAGUiRE, M., COPPEDGE, M. \& LINDBERG, S. (2015). "Electoral Democracy and Human Development”. V-Dem Institute Working Paper, 1-51.

GRAAFLAND, J. (2019). "Contingencies In The Relationship Between Economic Freedom And Human Development: The Role of Generalized Trust”. Journal of Institutional Economics, 1-16.

GRUBEL, H. G. (1998). "Economic Freedom And Human Welfare: Some Empirical Findings". Cato Journal, 18(2), 287-304.

GÜNEY, T. (2017). “Ekonomik Özgürlük ve İnsani Gelişmişlik”. Hitit Üniversitesi Sosyal Bilimler Enstitüsü Dergisi, 10(2), 1110-1120.

GÜZEL, A. E. \& ERDOĞAN, S. (2019). "Demokrasi, Gelir Eşitsizliği ve İnsani Gelişme İlişkisi: Türkiye Örneği”, Seventh International Mediterranean Social Sciences Congress (MECAS VII), Bandirma Onyedi Eylul University, Budapest, Hungary, September 10-12, 233-241.

IMANDOUST, S. B. \& MONTAZERI, S. (2013). "Democracy and Human Development Case Study: OPEC Member Countries”. International Journal of Engineering Research and Applications (IJERA), 3(3), 1441-1447. 
KHAN, A., SIDDIQUI, S.H., BUKHARI, S.H. \& IQBAL, S.M.H. (2020). "Human Development, Political Stability and Economic Growth: The way forward". Review of Economics and Development Studies, 6(2), 351-361.

KICSI, R. I. \& BURCIU, A. (2014). "Economic Freedom - A Catalyst for Development". The USV Annals of Economics and Public Administration, 14(2), 29-38.

KORLE, K., AMOAH, A., HUGHES, G., POMEYIE, P. \& AHİABOR, G. (2020). "Investigating The Role of Disaggregated Economic Freedom Measures and FDI on Human Development in Africa". Journal of Economic and Administrative Sciences, 119.

LIOTTI, G., MUSELLA, M. \& D’ISANTO, F. (2018). "Does Democracy Improve Human Development? Evidence from Former Socialist Countries". Eastern Journal Of European Studies, 9(2), 69-87.

MILLER, M. K. (2015). “Electoral Authoritarianism and Human Development”. Comparative Political Studies, 48(12), 1526-1562.

NAANWAAB, C. (2018). "Does Economic Freedom Promote Human Development? New Evidence from a Cross-National Study”. The Journal of Developing Areas, 52(3), 183198.

ÖZDEMİR, A. \& SALİHOĞLU, M. (2019). "Ekonomik ve Politik Faktörlerin İnsani Gelişmişlik Üzerindeki Etkileri”. Uluslararası Ekonomik Araştırmalar Dergisi, 5(3), 21-35.

ÖZER, H. (2004). Nitel Değişkenli Ekonometrik Modeller Teori ve Bir Uygulama. Nobel Basımevi, Ankara.

PEHLIVANOĞLU, F. \& ALABAŞ, M. M. (2017). "Kurumların İnsani Gelişme Üzerindeki Etkisi: Türkiye Örneği (1996-2014)". Kastamonu Üniversitesi İktisadi ve İdari Bilimler Fakültesi Dergisi, 17(3), 35-53.

ROSS, M. (2006). “Is Democracy Good for the Poor?”. American Journal of Political Science, 50(4), 860-874.

SAHA, S. \& ZHANG, Z. (2012). "The Impact of the Interaction between Economic Growth and Democracy on Human Development: Cross-National Analysis". ECU Publications 2012, Proceedings of Human Development and Capability Association (HDCA) Annual Conference. (pp. 12). Jakarta, Indonesia.

TSAI, M. C. (2006). "Does Political Democracy Enhance Human Development in Developing Countries? A Cross-National Analysis". American Journal of Economics and Sociology, 65(2), 233-268.

WELZEL, C. \& INGLEHART, R. (2001). "Human Development and the Explosion of the Democracy: Variations of Regime Change across 60 Societies". Discussion Paper FS III, Wissenschaftszentrum Berlin für Socialforschung (WZB), Berlin: 1-202. 